\title{
Definition of small-scale volcanic structures by electrical resistivity tomography: the Trentaremi cone, an example from the Campi Flegrei Caldera (Italy)
}

\author{
Maria Giulia Di Giuseppe ${ }^{1, *}$, Antonio Troiano ${ }^{1}$, Mauro Antonio Di Vito ${ }^{1}$, Renato Somma ${ }^{1}$, \\ Fabio Matano ${ }^{2}$ \\ ${ }^{1}$ Istituto Nazionale di Geofisica e Vulcanologia, Sezione di Napoli Osservatorio Vesuviano \\ ${ }^{2}$ Istituto per l'Ambiente Marino Costiero - Consiglio Nazionale delle Ricerche
}

\section{Article history}

Received February 23, 2017; accepted May 20, 2017.

Subject classification:

Exploration geophysics, Magnetic and electrical methods, Volcanology, Instruments and techniques, Geology.

\begin{abstract}
Small-scale buried structures in volcanic environments could present an extreme relevance, due to their link to the eruptive activity of individual monogenetic edifices, but require, to be detected, a high-resolution geophysical imaging. In such context, the Electrical Resistivity Tomography is often able to recover primary knowledge about the heterogeneity of the buried layers, despite the reduced investigation depth. In this paper an example of such matter is proposed, concerning the Posillipo hill, in the southeastern sector of the Campi Flegrei Caldera (Italy), where an electrical resistivity survey has been carried out in the roman age Seiano tunnel. In such a way, details of the Trentaremi tuff cone buried structure have been revealed, with a maximum depth of exploration of about $100 \mathrm{~m}$. The obtained results have been compared with geological observations on the exposed rocks, interpreting their underground continuation. The geophysical image reconstructs the inner structure of the Trentaremi cone. At the same time, its relationships with respect to the deposits belonging to Neapolitan Yellow Tuff eruption have been highlighted. Reconstructing this stratigraphic sequence, indications about the past volcanic dynamics have been obtained, presenting valuable implications for the future activity forecasting.
\end{abstract}

\section{Introduction}

The geophysical imaging represents a powerful tool for acquiring detailed knowledge about the buried structures in a wide range of settings [Namson and Davis 1998, Bedrosian et al. 2007, Troiano et al. 2009]. In particular, the volcanic districts are nowadays well characterized firstly thanks to the structural knowledge gained through the different geophysical exploration methods. In such a sense, the applied geophysics have assumed a prominent role in the volcanological studies providing useful results in terms of volcan- ic hazard evaluation and mitigation [Chiarabba et al. 2000, Finizola et al. 2006, Battaglia et al. 2008, De Siena et al. 2010, Capuano et al. 2013, Casas et al. 2013, Brothelande et al. 2014].

Once integrated with the findings of field survey on exposed rocks, the indirect imaging permits the reconstruction of the overall stratigraphic sequence, constraining the lithological and geometrical features of the edifices. In such context, methods reconstructing the electrical resistivity distribution are among the most powerful techniques, thanks to the large variability and great diagnostic capability of this parameter in volcano-geothermal areas [Spichak and Manzella 2009, Berkthold, 1983, Troiano et al. 2008, Troiano et al. 2014]. In particular, the Electrical Resistivity Tomography (ERT) has a specific capability to resolve local small-scale features of the buried deposits, thanks to its extremely high-resolution power [Casas et al. 2013, Di Giuseppe et al. 2015, Isaia et al. 2015]. Often, such kind of structures presents a great volcanological interest, despite their limited spatial extension, being their articulate morphology an indicator about the dynamic of such short time-life monogenetic volcanoes. The understanding of the depositional characteristic of events lasting usually few days or weeks could in fact highlight great information about the way the eruptions develop.

In this paper an example of such a capability is given, related to an application of the ERT imaging to the Campi Flegrei Caldera (CFc) area (Figure. 1), which coastal zone results particularly exposed to a series of natural and anthropogenic hazards, including earthquakes, landslides and erosion [Beneduce et al. 
1988]. CFc geophysical imaging has already been undertaken, but in several sectors the stratigraphy still results uncharacterized.

Here, the buried structures of the Trentaremi Tuff Cone, located in the southeastern sector of the caldera, are investigated (Figure 1). This sector results relatively less interested by ground deformation during the recent unrest [D'Auria et al. 2011, Troiano et al. 2011], but its morphology, strictly related to the intense past dynamics, could be indicative about the character of the future scenarios in the caldera. The structures are investigated through ERT imaging, ending in an electrical model up to an about one hundred of meters depth. The ERT findings have been compared with the (poor) available knowledge about the structure of this sector and geologically interpreted, considering also the field observations on the exposed rocks, which underground continuation has been detected through the indirect imaging. In such way, the stratigraphic sequence of that part of the caldera has been reconstructed. Furthermore, the morphology of the Trentaremi tuff cone and its relationship with the surrounding deposits highlights knowledge about the volcanism occurred between the two main events that formed the caldera, the Campanian Ignimbrite (CI) and the Neapolitan Yellow Tuff (NYT).

\section{The study area}

The Campi Flegrei caldera $(\mathrm{CFc})$ includes a continental and a submerged part [Somma et al. 2016]. It is an active volcano which history was dominated by two huge eruptions happened at about 39 and $15 \mathrm{ka}$ [Rosi and Sbrana 1987, Orsi et al. 1996]. Vertical ground movements with rates from centimeters to meters per year characterize the dynamics of this area even during quiescent periods [Dvorak and Mastrolorenzo 1991, Di Vito et al. 1999, Iuliano et al. 2016]. Since 1969, the area has been affected by several phases of ground uplift following several centuries of subsidence dating back to AD 1538, when the last eruption occurred [Di Vito et al. 1987, Di Vito et al. 2016]. The largest recent episodes of intense ground deformation are the two unrests of 1969-1972 and 1982-1984, causing a cumulative maximum uplift of over $3.5 \mathrm{~m}$, accompanied by intense seismicity [D’Auria et al. 2011]. After a period of relative quiescence, a new unrest phase has begun starting from the 2011 characterized by a cumulative maximum ground deformation of about $0.34 \mathrm{~m}$ [Isti-

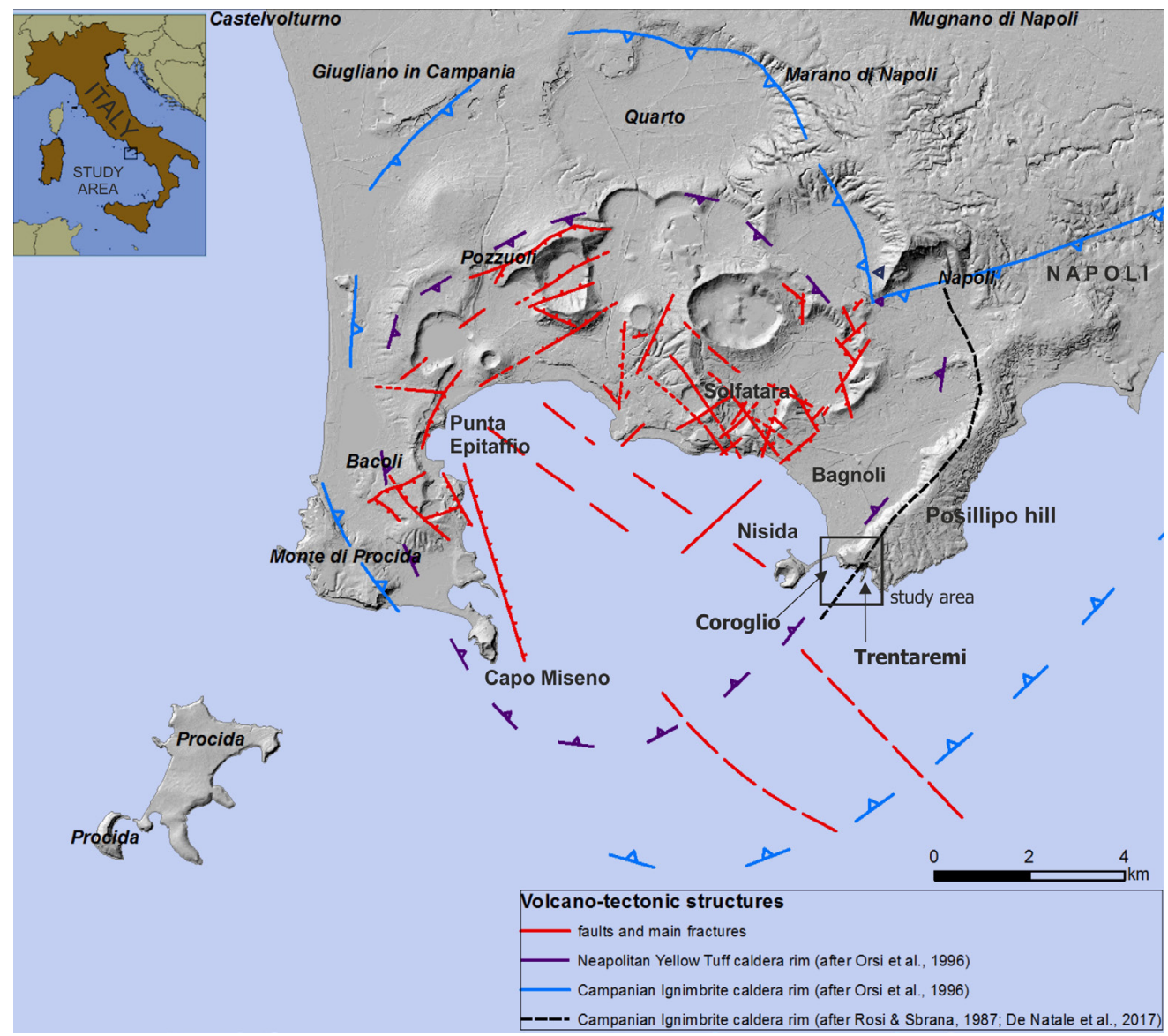

Figure 1. Structural sketch map of the Campi Flegrei caldera (Italy). Faults and main fractures have been highlighted in red. Neapolitan Yellow Tuff rim has been indicated in purple [after Orsi et al. 2006]. Campanian Ignimbrite rim also is indicated, in blue [after Orsi et al. 1996] and black [after Rosi and Sbrana, 1987 and De Natale et al. 2017]. In the black box the study area is highlighted. 
tuto Nazionale di Geofisica e Vulcanologia et al. 2017]. Only recently, the most active zone within the $\mathrm{CFc}$, located in the proximity of the Solfatara crater, has been surveyed by electrical and EM methods [Troiano et al. 2014, Di Giuseppe et al. 2015, Isaia et al. 2015]. The large-scale structure of the volcano, down to a few kilometers depth, has been fairly well imaged by natural (MT) and controlled (CSAMT) magnetotelluric survey. The recognized structure have been interpreted as the evidence of a dominating maar-diatreme evolution of the Solfatara area [Isaia et al. 2015]. Numerical studies have shown how this structure could result of extreme relevance into the dynamics of the overall caldera unrest [Troiano et al. 2011, Carlino et al. 2015 a,b, Chiodini et al. 2016].

Less is known about other parts of the CFc and its more external parts still result poorly or not constrained. Among them, the Posillipo hill is a ridge localized on the eastern rim of the caldera along a coastal segment of the Napoli metropolitan area. The hill reaches an altitude of $150 \mathrm{~m}$ above sea level (a.s.1.). The Coroglio and Trentaremi cliffs, on the southwestern side of the hill, constitutes its rocky front, directly exposed to the wave erosion action, that was formed during the large caldera collapse associated to the Neapolitan Yellow Tuff (NYT) eruption, at $15 \mathrm{ka}$ [Deino et al. 2004]. The Posillipo structure constitutes the eastern boundary of the Bagnoli-Fuorigrotta depression and represents a segment of the structural border of the caldera [Orsi et al. 1996, Vitale and Isaia, 2014], partially modified by erosive and dismantling processes [Calderoni and Russo, 1998]. Prior to the NYT eruption, the area was mostly emerged and characterized by older vents, namely the Trentaremi tuff cone, whose products have been overlain by the NYT deposits [Scarpati et al. 2013]. The youngest volcanic activity in the area is represented by the eruption of Nisida tuff cone, dated at 4 ka [Di Renzo et al. 2011, Scarpati et al. 2013].

An artificial tunnel from the Roman period, called "Grotta di Seiano", crosses the ridge interior. It passes through the Posillipo hill (Figure 2). It is believed that the tunnel was originally a quarry for the retrieval of building material and subsequently had function vehicular access to the villa Pausilypon [Damiano et al. 2008]. The Seiano cave is located at an altitude of ca. $30 \mathrm{~m}$ a.s.l. and it is about $770 \mathrm{~m}$ long, NW-SE trending, from 3 to $7 \mathrm{~m}$ wide, and 4 to $8 \mathrm{~m}$ high. Starting from the

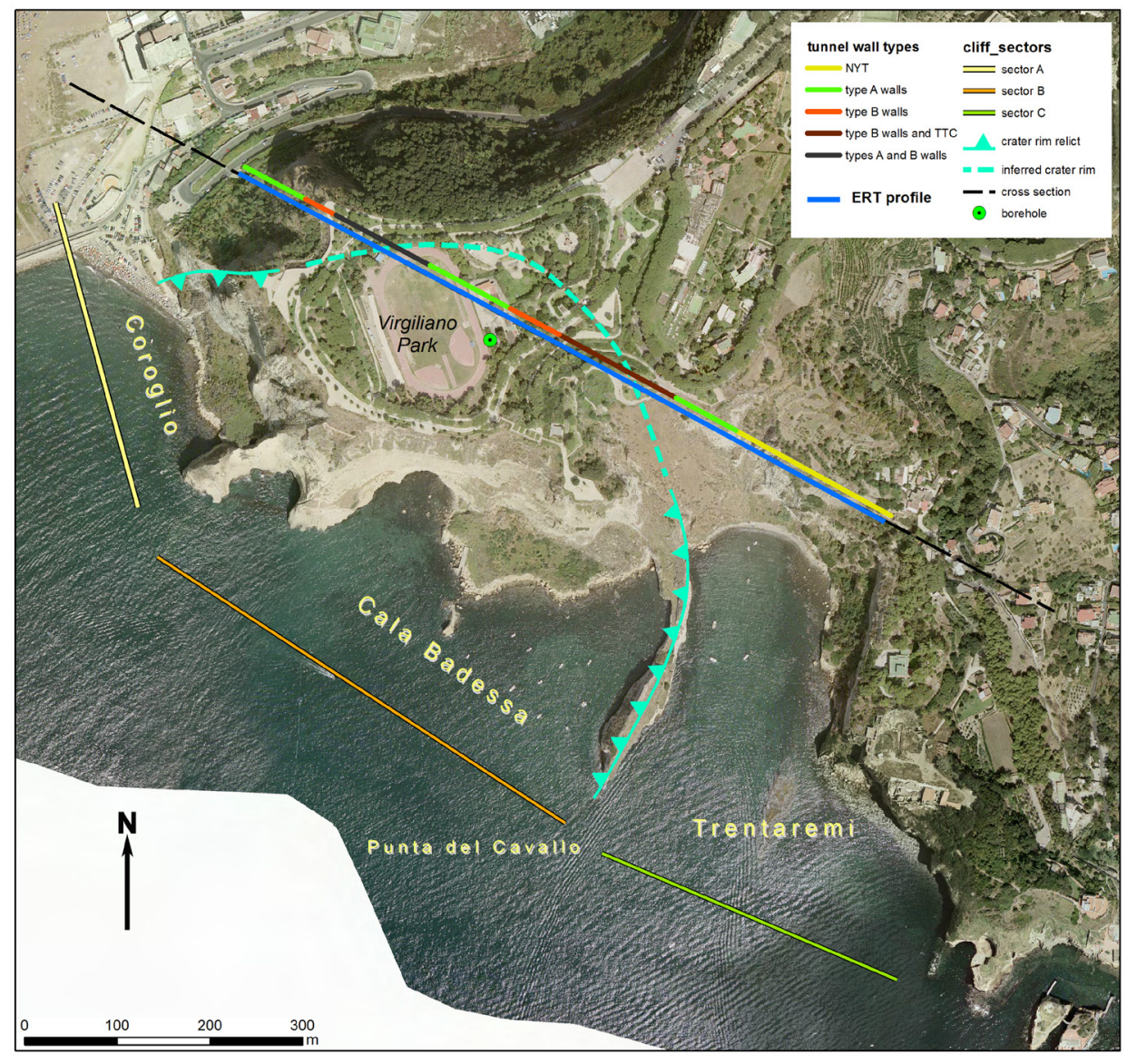

Figure 2. The study area, highlighted in Figure 1, is here magnified. The three main sectors of Coroglio (A), Cala Badessa (B) and Trentaremi (C) are indicated. The Trentaremi crater rim is evidenced with a green line. The Seiano cave location, where the ERT profile has been carried on, is indicated with a black line (also the differences in the covering walls type are evidenced). 
western entrance of the tunnel it is possible to discern that this part of the hill is constituted almost entirely by NYT, mainly lithified and dipping northeastward. This tuff is mantled by a sequence of loose pyroclastics (LP, mainly pumice lapilli and ash) interbedded with paleosols, with the same attitude of the tuff and emplaced by fallout and minor pyroclastic density currents of major eruptions of the last $15 \mathrm{ka}$. Roman design for the ventilation and lighting envisaged the construction of lateral tunnels, which open in the face of the cliff over Trentaremi Bay. The first $471 \mathrm{~m}$ of the Seiano cave are completely cased with walls and reinforcements of Roman and more recent ages. At $471 \mathrm{~m}$ there is a small tunnel excavated toward the cliff exposing the pyroclastic material of the TTC, composed by coarse pumice bombs and lapilli. After this small tunnel the cave is again cased with walls of different ages for about $123 \mathrm{~m}$. The eastern exit of the tunnel is free of case and exposes the NYT, which has an attitude toward east progressively decreasing between $20^{\circ}$ and $12^{\circ}$. The NYT is strongly lithified due to a zeolitization process. There are other small tunnels at 565 and $668 \mathrm{~m}$ from the W entrance excavated in NYT lithoid facies, not cased. In the last decades several block failures occurred along the Coroglio and Trentaremi cliffs [Matano et al. 2016] due to fracturing and weathering of tuffaceous rock mass. Laser scanning surveys have been performed on selected cliffs (Figure 3) in order to analyze the susceptibility to failures of Phlegrean tuffs [Matano et al. 2015, 2016, Somma et al. 2015].

\section{Geological field data}

The southeastern cliffs of the Posillipo hill show the geological sequence of the rocks that constitute the promontory (Figure 3). In order to reconstruct this rock sequence, a geological survey has been performed both along the Posillipo hill coast and slopes and in the Seiano Roman tunnel. The retrieved sequence is described from top downward:

1 - All the upper portion of hill, well visible along the cliffs (Figure 3), is composed by a loose pyroclastic sequence (LP). It is a $15 \mathrm{~m}$ to $30 \mathrm{~m}$ thick succession of pumice and ash layers interbedded with paleosoils. The pyroclastic layers were generated by recent explosive eruptions ( $<15 \mathrm{ka}$ ) of the $\mathrm{CFc}$, whereas paleosoils were formed during quiescent periods of the caldera [Di Vito et al. 1999]. This succession has a general sub-horizontal attitude and overlies the NYT. The stratigraphic reconstruction of a continuous core drilled in the central area of "Parco Virgiliano (top of the Posillipo hill - Figure 2), confirms the overlapping between LP and NYT at depth of ca. $30 \mathrm{~m}$ [Maresca et al. 2014].

2 - The main part of the hill is composed by Neapolitan Yellow Tuff. It is formed by a sequence of coarse and fine ash layers and lenses, strongly stratified in the basal portion (Lower Member, Orsi et al. 2004) and massive in the main intermediate and upper parts (Upper Member, Orsi et al. 2004). The sequence, mainly emplaced by pyroclastic density currents is characterized by high thickness variations with thickening in the preexisting lowlands. The NYT is affected by a post-deposition lithification process due to zeolitization, whose intensity increases in the thicker parts, evidenced by the yellowish color of the deposit. The lower and upper parts of this unit are less lithified and gray in color. This succession is also characterized by a complex system of fractures, mostly steep and planar with highly variable density, with well-developed NE-SW and NW-SE directions, and subordinate N-S and E-W trends [Di Vito et al. 1999, Froldi, 2000, Matano et al. 2016]. The fracture patterns genetically associated with the structural evolution of the caldera rim overlaps with the regional extensional structures [Calcaterra et al. 1988, Acocella, 2010, Vitale and Isaia, 2014].

3 - The remnants of the Trentaremi Tuff cone (TTC) lie below the NYT. The contact is well exposed along the Coroglio cliff (Figure. 3a) where the rim and outer and inner slopes are well visible. The finely laminated, scarcely lithified ash layers composing the tuff cone dip towards NW (outer slopes) and SE (inner slopes) (Figure 2 and 3a). In the central sector of the cliff, known as Cala Badessa (Figure $3 \mathrm{~b})$, the TTC is filled almost completely by the NYT down to the sea. Here the NYT is $>100$ $\mathrm{m}$ thick and is almost completely lithified (Yellow facies). This area likely corresponds to the TTC crater. Along the Trentaremi bay and cliff, located East of Cala Badessa (Figure 3c), the eastern portion of the TTC edifice is exposed. In particular the rim and the inner and outer slopes are well visible, dipping toward West and East, respectively. The TTC also constitutes the Punta del Cavallo small peninsula. Along this sector of the cliff the TTC is mantled by NYT with significant thin- 


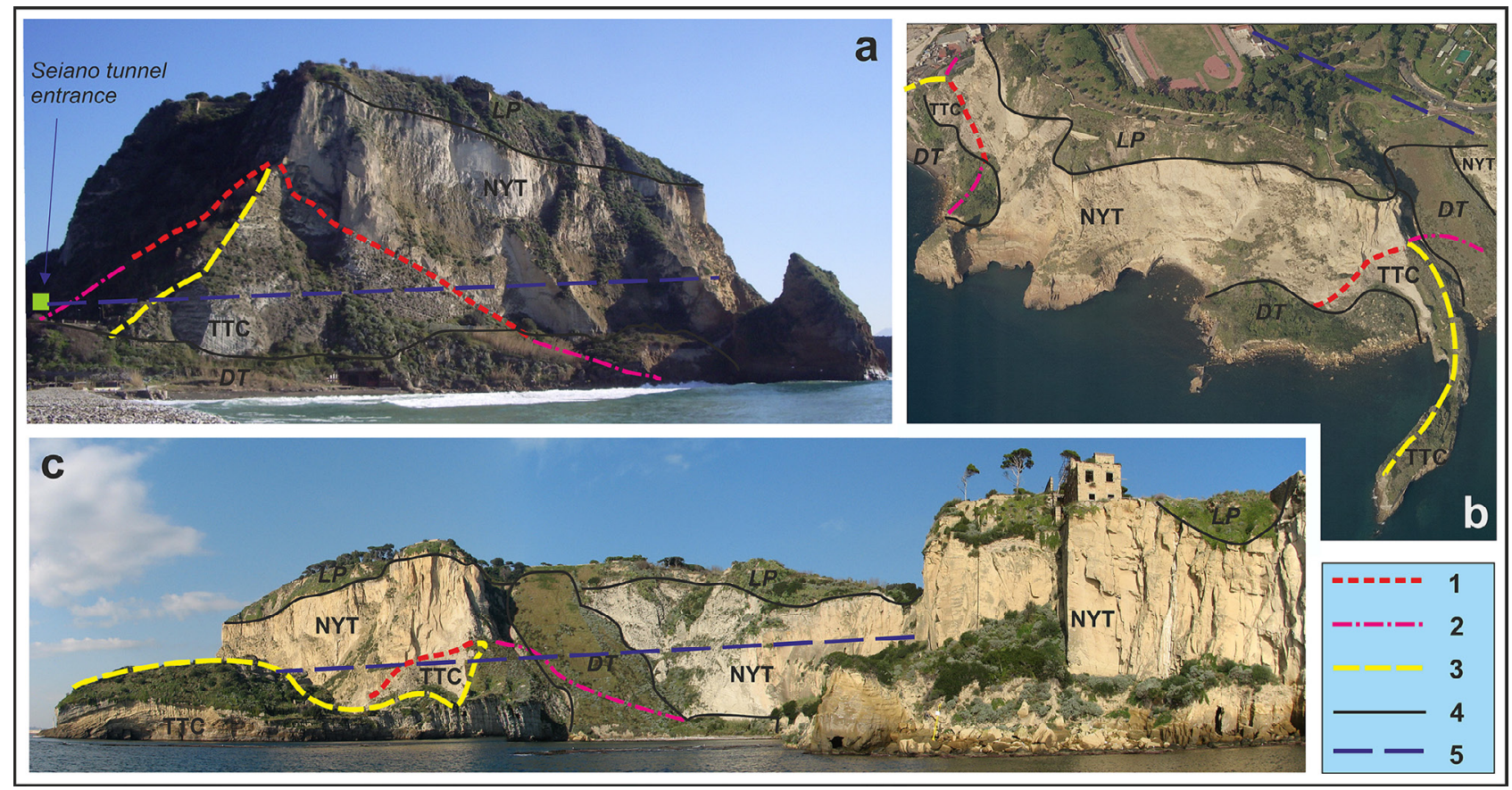

Figure 3. Stratigraphic features along the cliffs of three sectors of the study area evidenced in Figure 2. a) northern sector (Coroglio); b) central sector (Cala Badessa); c) southern sector (Trentaremi). Lines on the panels (explained in Legend) respectively indicate: 1. Exposed contact between the Trentaremi Tuff Cone (TTC) and Neapolitan Yellow Tuff (NYT) units; 2. Buried contact between the TTC and NYT units; 3. Relict of the Trentaremi Tuff Cone rim. 4. Stratigraphic contact between recent units (LP - loose yroclastic sequence; DT - slope debris) and volcanic units (NYT, TTC). 5. Tunnel path projection on cliff or on ground.

ning over the rim of the preexisting cone. The NYT becomes very thick toward East, where the NYT composes all the cliffs down to the sea and is almost completely lithified. From a lithological point of view, the TTC consists of a highly stratified sequence of layers composed mainly by fine to coarse ash and by pumice lapilli and bombs. The tuff is generally low lithified due to a low degree of a zeolitization post-deposition process, apart from the Punta del Cavallo peninsula (Figure 2) lower strata. Locally (Cala Badessa, Figure 2) the TTC and NYT are separated by a thin sequence of paleosols and ash deposits [Orsi et al. 1996]. The rock face associated with the Trentaremi unit is markedly controlled by the bedding of pyroclastic deposits and is characterized by diffused vesicles and vacuoles due to expansion of gas during emplacement and to differential erosion. The low lithification of the unit does not allow the observation of well-developed fractures in the rock face.

The analysis of geological exposures along the entrances and the interiors of the Seiano tunnel, described above, permits the integration of the described geological sequence and gives a feedback about the complex geological structure of the area.

\section{The ERT survey}

Geological field observations and literature data from boreholes help in reconstructing the stratigraphy outcropping in the coastal area of the Posillipo hill. However, the buried volcanic sequences along the rim of the hill can be well defined just through a tomographic approach. To such aim, an electrical survey has been carried in the roman age Seiano cave, a tunnel cutting the Posillipo hill. In such a way, an attempt has been undertaken to have more information about the electrical resistivity distribution vs. depth, taking into account also the logistic characteristic of the area.

\subsection{Survey outline}

The ERT Profile has been made in the interior of the Seiano tunnel, across a $700 \mathrm{~m}$ long profile covering almost its whole extension (ERT Profile in Figure 2) following the NW-SE trend of the Seiano cave. Along the profile a dipole-dipole (DD) electrode configuration has been deployed. The DD has been preferred with respect to other configurations due to its penetration depth that results greater with respect to other kind of source-receiver coupling, facilitating depth evaluation of anomaly source bodies [Ward, 1990]. Moreover, it results compact and particularly sensitive to the presence of lateral discontinuity in the electrical resistivity due to the alternation of anomalous bod- 
ies along the survey line. As final consideration, the $2 \mathrm{D}$ character of the acquisition, necessary due to the Seiano cave morphology, has to be considered. In principle, the possibility of lateral effects on the ERT image cannot be excluded, but literature studies confirms the consolidated field tendency to adopt conventional $2 \mathrm{D}$ resistivity arrays, which lighten the data collection with a slight lost of resolution (Nyquist et al. 2007, Moreira et al. 2016). A full array of 70 electrodes has been installed, separated by $10 \mathrm{~m}$ minimum electrode spacing. A multi-channels IRIS Syscal Pro ${ }^{\circledR}$ System has been employed in order to carry on the survey, presenting a maximum output voltage and current of 800 $\mathrm{V}$ and $2 \mathrm{~A}$, respectively.

A 2D inversion of the ERT profile has been obtained using the RES2DINV ${ }^{\circledR}$ commercial software [Loke and Barker, 1996]. The inversion algorithm used is based on a smoothness constrained least-squares inversion [Sasaki, 1994]. The inverted section, called electrical tomography, represents the result of an iterative process that tends to minimize the difference between measured and calculated resistivity values [Loke and Barker, 1996]. The Root Mean Squared (RMS) error gives a measure of this difference. In the present case an about 7 RMS have been obtained, which appears an acceptable result, being of the same magnitude of the values that characterize inversion of data collected in volcanic environment [Van Zijl, 1985, Bruno et al. 2007, Loke, 2014, Di Giuseppe et al. 2015].

\subsection{ERT results}

The obtained tomographic section of the ERT Profile is shown in Figure 4. A reconstruction of the electrical features located in the first $120 \mathrm{~m}$ with respect to the Seiano tunnel ground level (located about at $30 \mathrm{~m}$ a.s.1.) is obtained. Essentially, a first resistive layer (of a few hundreds of $\Omega \cdot m$, indicated as A in Figure 4) has been retrieved in the first $40 \mathrm{~m}$ depth. Alternated resistive bodies characterize this heterogeneous layer along its whole length. This resistive stratum overlies a more conductive zone (presenting an electrical resistivity of a few $\Omega \cdot m$; indicated as B in Figure 4). The interface between these two layers appears well evident in the section, as indicated in Figure 4 with a dashed white line. It is located at depths starting from about $10 \mathrm{~m}$ below the sea level (b.s.l.) and it is characterized by an almost horizontal shape. A further anomaly appears in the ERT findings as a resistive oblique body (characterized by an about $200 \Omega$ m resistivity; indicated as $\mathrm{C} 1$ in Figure 4) cutting almost in half the lower conductive layer. The head of this resistive feature emerges at about $350 \mathrm{~m}$ along the profile and it is located at a 10 $\mathrm{m}$ b.s.l. The anomalous body extends downward to the SE up to the end of the resolved depths. A second resistive anomaly appears at about $150 \mathrm{~m}$ along the profile, indicated as C2 in Figure. 4. It is centered at about 10 $\mathrm{m}$ b.s.l. and it is characterized by a several hundreds of $\Omega \cdot \mathrm{m}$ electrical resistivity.

\section{Volcanological interpretation and discussion}

As described in the previous sections, the knowledge gained through the geological field data acquired both in the Seiano tunnel and in the Posillipo hill exposed sectors (Coroglio, Cala Badessa, Trentaremi) indicate the sequence of strata displayed in Figure 5, which can be listed from top downward as:

1. Sequence of pumice, ash and paleosol layers $(<15$ ka; LP in green);

2. Neapolitan Yellow Tuff (15 ka; NYT in brown);

3. Trentaremi Tuff Cone ( $>15 \mathrm{ka}$; TTC in orange).

Figure 5 shows also the TTC remains partially exposed along one of the lateral tunnels of the Seiano cave.

The sequence of Figure 5, however, consists just in a qualitative hypothesis of the real rocks present in the underground. Any heterogeneity in the inner morphology can be appreciated just through the quantitative and rigorous approach that concerns the applied geophysics. In the same time, the guidelines provided from the geological field data results of great relevance for the resolution of the ambiguous linking between the geophysical parameter and the lithotypes. In the presented model, the different classes of resistivity values are associated to geological units through what observed in the exposed rocks. This integration between geological field data and geophysical prospecting is summarized in Figure 6. Along the central sector of Seiano tunnel the alternation of resistive and conductive bodies which characterize the heterogeneous layer indicated with A in Figure 4 well corresponds with the thickening of the NYT sequence (the yellow layer) filling the TTC crater depression and to the TTC rims (the orange layer), on the outer edges, as also evidenced by the analysis of the Coroglio cliff. The NYT high degree of zeolitization and its low porosity result compatible with the observed high resistivity in the central part of this first layer. The underlying TTC layers are characterized by oblique shapes deepening toward the East and likely West, representing the outer flanks of the tuff cone, characterized by dense stratification and deepening of the strata both toward the outer flanks of the cone and toward the crater. This 


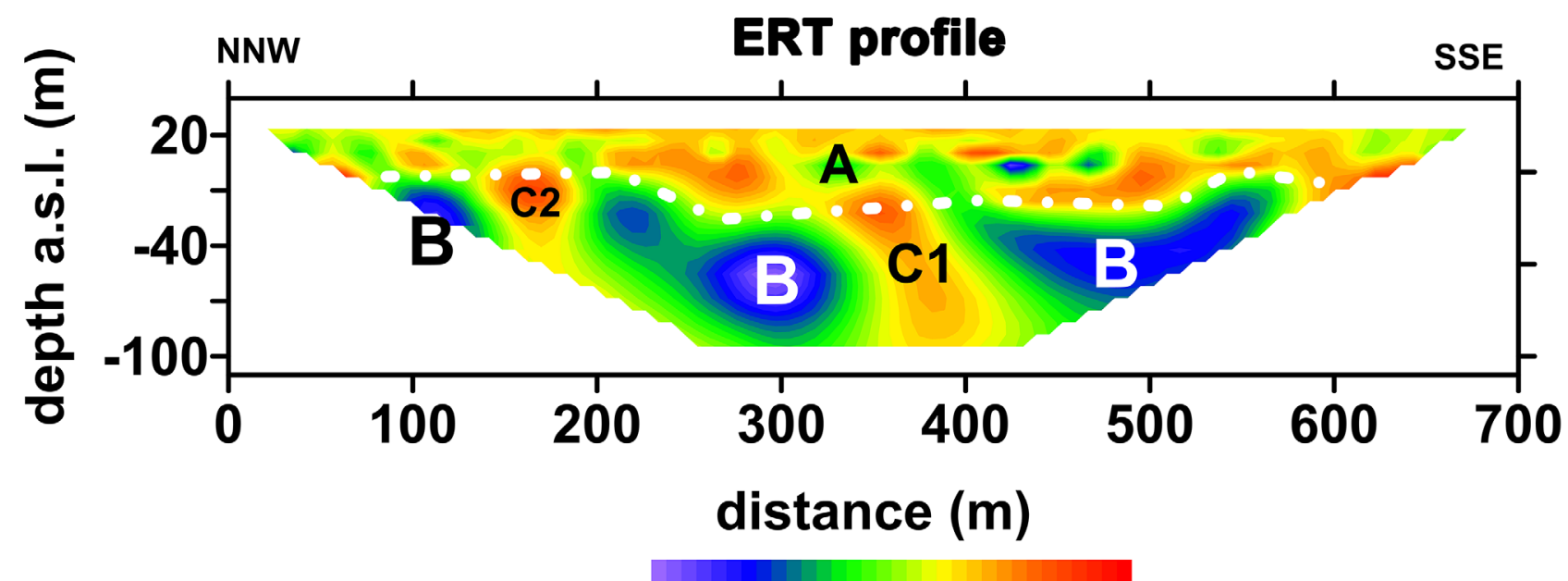

\section{$\begin{array}{llllll}-0.4 & 0.2 & 0.8 & 1.4 & 2 & 2.6\end{array}$ \\ Log Resistivity $\left(\mathrm{Ohm}^{*} \mathrm{~m}\right)$}

Figure 4. Tomographic section of the ERT Profile, which location has been indicated in Figure 2. The main electrical anomalies, discussed in the text, are labeled with capital letters. A common logarithmic scale has been adopted for the electrical resistivity.

geometry is confirmed by the observations along the cliff (Figure. 3). The conductive body indicated as B in Figure. 4 is localized within the crater area of TTC and could be associated with a heterogeneous and coarse filling of the TTC crater zone, in turn associated with the $\mathrm{C} 1$ and $\mathrm{C} 2$ resistive bodies shown in the ERT tomography. In such interpretative context, the ERT tomogram gives consistence to the geological framework of the Trentaremi structure, evidencing its rims and the boundary between the related deposits and the ones belonging to the NYT eruption.

As last remark, the higher conductivity of the $\mathrm{B}$ zone could be associated with the major permeability of the filling material and consequently to the higher water content, dominantly seawater. The surface of the ground water associated to the ingression of the seawater in the Posillipo hill is also evident along the profile. It is lower in the center of the profile and it rises of few meters at the western and eastern margins of the section. This feature can be explained with the major distance from the coast of the central area of our profile determining the deepening of the top of the salt ground water, below the fresh ground water (with higher resistivity).

\section{Conclusion}

An ERT survey, carried out along the roman age Seiano cave, located in the eastern sector of the CFc, has been presented and discussed in order to reconstruct the buried volcanic structures. The previously available knowledge about the volcano-tectonic structure of the area was limited to the qualitative recon-

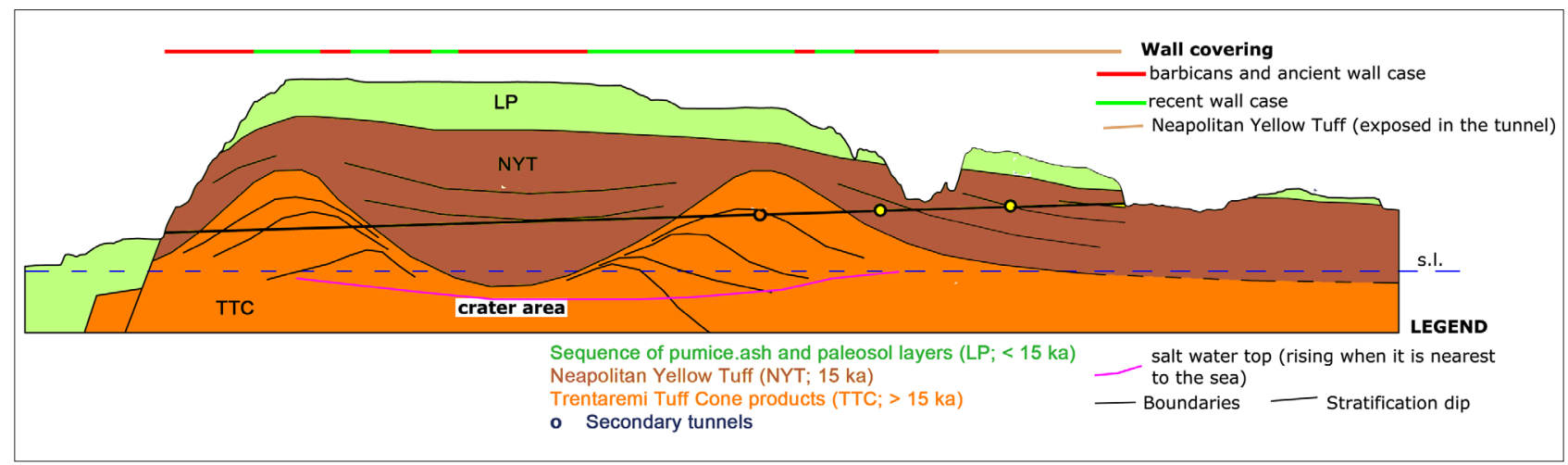

Figure 5. Sketch of the volcanic buried structure in the study area, obtained considering the geological data collected both along the Seiano tunnel and the Coroglio-Trentaremi sea-cliff. Contrasts between the main layers are evidenced with distinct colors. Also the characteristics of the wall covering are reported. 


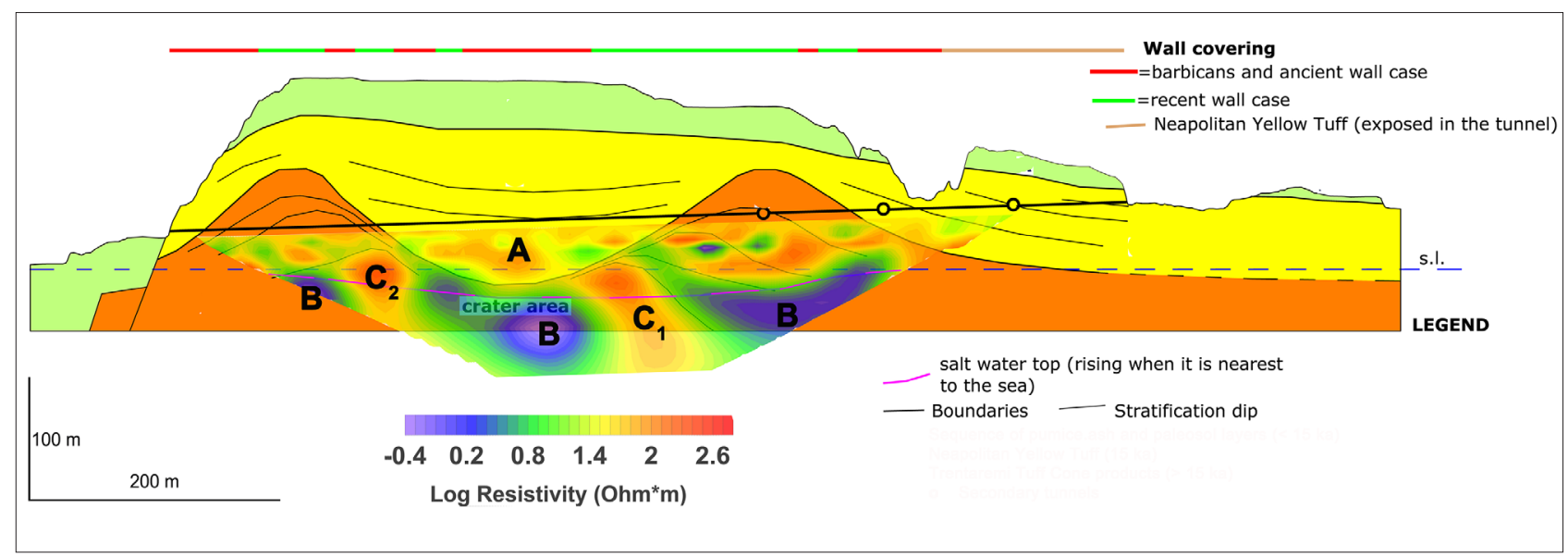

Figure 6. Combination of ERT imaging (shown in Figure 4) and geological sketch related to the Seiano tunnel and the Coroglio-Trentaremi sea-cliff (shown in Figure 5).

struction of the main layering, which were possible to extrapolate from the geological field observations.

The ERT findings, once geologically interpreted considering this information, provides a quantitative high-resolution reconstruction of the Trentaremi tuff cone structure. The morphology of the cone results well evident in the section, together with its relationship with the surrounding deposits. In such way, an insight is provided about the volcanism occurred between the two main events that formed the caldera, the Campanian Ignimbrite (CI) and the Neapolitan Yellow Tuff (NYT).

The presented application marks the effectiveness of ERT tomography to reconstruct the main stratigraphic sequence also in its details, constraining the lateral and vertical heterogeneity of the structures. This remarkable ability of the ERT tomograms represents a key feature in heterogeneous environments such as the volcanic ones where the complex alternation of deposits gives an extreme relevance also at small structures. The extensive application of ERT in the Campi Flegrei area, following the example of the Trentaremi cone, could give a deeper insight in the connected volcanism and the adoption of a time-lapse approach could result of relevance in the understanding of the present dynamic.

Acknowledgements. Study performed with financial support from the MIUR "PON01-1525 MONICA" and in the framework of the INGV-DPC Research Agreement 2012-2015 "All. A". The authors wish to thank Giuseppe Brandi, dr. Roberta Esposito, dr. Alessandro Fedele and Giuseppe Ricciardi for the technical support during the field operations.

\section{References}

Acocella, V. (2010). Evaluating fracture patterns within a resurgent caldera: Campi Flegrei, Italy. Bull. Volcanol., 72, 623-638. Battaglia, J., A. Zollo, J. Virieux and D. Dello Iacono (2008). Merging active and passive data sets in traveltime tomography: the case study of Campi Flegrei caldera (Southern Italy). Geophysical Prospecting, 56(4), 555-573.

Bedrosian, P.A., N. Maercklin, U. Weckmann, Y. Bartov, T. Ryberg and O.Ritter, (2007). Lithology-derived structure classification from the joint interpretation of magnetotelluric and seismic models. Geophysical Journal International, 170(2), 737-748.

Beneduce, P., G. D’Elia and M. Guida (1988). Morfodinamica dei versanti dell'area flegrea (Campania): erosione in massa ed erosione lineare. Mem. Soc. Geol. It., 41, 949-961.

Berktold, A. (1983). Electromagnetic studies in geothermal regions. Geophysical surveys, 6(1-2), 173200.

Brothelande, E., Finizola, A., Peltier, A., Delcher, E., Komorowski, J. C., Di Gangi, F., ... \& Legendre, Y. (2014). Fluid circulation pattern inside La Soufrière volcano (Guadeloupe) inferred from combined electrical resistivity tomography, self-potential, soil temperature and diffuse degassing measurements. Journal of Volcanology and Geothermal Research, 288, 105-122.

Bruno, P.P.G., G.P. Ricciardi, Z. Petrillo, V. Di Fiore, A. Troiano and G. Chiodini (2007). Geophysical and hydrogeological experiments from a shallow hydrothermal system at Solfatara Volcano, Campi Flegrei, Italy: Response to caldera unrest. Journal of Geophysical Research: Solid Earth, 112 (B6).

Calcaterra, D., A. Gianni, A. Ietto and G. Pappone (1988). Sistemi di fratturazione nei tufi post-calderici dell'area flegrea. Mem. Soc. Geol. It., 41, 935-940.

Calderoni, G. and F. Russo (1998). The geomorphological evolution of the outskirts of Naples during the Holocene: A case study of the Bagnoli-Fuorigrotta 
depression. Holocene, 8 (5), 581-588.

Capuano, P., G. Russo, L. Civetta, G. Orsi, M. D’Antonio and R. Moretti (2013). The active portion of the Campi Flegrei caldera structure imaged by 3D inversion of gravity data. Geochemistry, Geophysics, Geosystems, 14(10), 4681-4697.

Carlino, S., R. Somma, A. Troiano, M.G. Di Giuseppe, C. Troise and G. De Natale (2015a). Geothermal investigations of active volcanoes: the example of Ischia island and Campi Flegrei caldera (Southern Italy). In G. Lollino, A. Manconi, J. Clague, W. Shan and M. Chiarle (ed.s), Engineering Geology for Society and Territory-Volume 1: Climate Change and Engineering Geology, 369-372, Springer International, doi: 10.1007/978-3-319-09300-0_70.

Carlino S., C.R.J. Kilburn, A. Tramelli , C. Troise, R. Somma and G. De Natale (2015b). Tectonic stress and renewed uplift at Campi Flegrei caldera, southern Italy:New insights from caldera drilling (2015b) Earth and Planetray Sceince Letterss 420, 23-29.

Casas, A., Barde-Cabusson, S., Bolós, X., Pedrazzi, D., Lovera, R., Himi, M., ... \& Martí, J. (2013, September). Illuminating the Internal Structure of Two Monogenetic Volcanoes by ERT (La Garrotxa Volcanic Field, Spain). In Near Surface Geoscience 201319th EAGE European Meeting of Environmental and Engineering Geophysics.

Chiarabba, C., Amato, A., Boschi, E., \& Barberi, F. (2000). Recent seismicity and tomographic modeling of the Mount Etna plumbing system. Journal of Geophysical Research, 105(10), 923-10.

Chiodini, G., Paonita, A., Aiuppa, A., Costa, A., Caliro, S., De Martino, P., ... \& Vandemeulebrouck, J. (2016). Magmas near the critical degassing pressure drive volcanic unrest towards a critical state. Nature communications, 7.

Damiano, N., R. Maresca, L. Nardone and D. Galluzzo (2008). Esperimento sul rumore sismico alla Grotta di Seiano (Campi Flegrei): tecniche di acquisizione e primi risultati. Atti VI Convegno Nazionale di Speleologia in Cavità Artificiali-Napoli, 30.

D’Auria, L., Giudicepietro, F., Aquino, I., Borriello, G., Del Gaudio, C., Lo Bascio, D., ... \& Ricco, C. (2011). Repeated fluid-transfer episodes as a mechanism for the recent dynamics of Campi Flegrei caldera (1989-2010). Journal of Geophysical Research: Solid Earth, 116(B4).

Deino, A. L., G. Orsi, S. de Vita and M. Piochi (2004). The age of the Neapolitan Yellow Tuff caldera-forming eruption (Campi Flegrei caldera-Italy) assessed by ${ }^{40} \mathrm{Ar} /{ }^{39} \mathrm{Ar}$ dating method. Journal of Volcanology and Geothermal Research, 133, 157 - 170.

De Siena, L., E. Del Pezzo and F. Bianco (2010). Seismic attenuation imaging of Campi Flegrei: Evidence of gas reservoirs, hydrothermal basins, and feeding systems. Journal of Geophysical Research: Solid Earth, 115(B9).

Di Giuseppe, M. G., A. Troiano, A. Fedele, T. Caputo, D. Patella, C. Troise and G. De Natale (2015). Electrical resistivity tomography imaging of the near-surface structure of the Solfatara crater, Campi Flegrei (Naples, Italy). Bulletin of Volcanology, 77(4), 1-15.

Di Renzo, V., I. Arienzo, L. Civetta, M. D’Antonio, S. Tonarini, M.A. Di Vito and G. Orsi (2011). The magmatic feeding system of the Campi Flegrei caldera: architecture and temporal evolution. Chemical Geology, 281(3), 227-241.

Di Vito, M.A., L. Lirer, G. Mastrolorenzo and G. Rolandi (1987). The Monte Nuovo eruption (Campi Flegrei, Italy), Bull. Volc., 49, 608-615.

Di Vito, M. A., R. Isaia, G. Orsi, J. Southon, S. De Vita, M. d'Antonio, L. Pappalardo and M. Piochi (1999). Volcanism and deformation since 12,000 years at the Campi Flegrei caldera (Italy). Journal of Volcanology and Geothermal Research, 91(2), 221-246.

Di Vito, M. A., V. Acocella, G. Aiello, D. Barra, M. Battaglia, A. Carandente, C. Del Gaudio, S. de Vita , G.P. Ricciardi, C. Ricco, R. Scandone and F. Terrasi (2016). Magma transfer at Campi Flegrei caldera (Italy) before the $1538 \mathrm{AD}$ eruption. Scientific Reports, 6, 32245. http: / / doi.org/10.1038/ srep32245

Dvorak, J. and G. Mastrolorenzo (1991). The mechanisms of recent vertical crustal movements in Campi Flegrei caldera, southern Italy, Spec. Pap. Geol. Soc. Am., 263, 1-47.

Finizola, A., Revil, A., Rizzo, E., Piscitelli, S., Ricci, T., Morin, J., ... \& Sortino, F. (2006). Hydrogeological insights at Stromboli volcano (Italy) from geoelectrical, temperature, and CO2 soil degassing investigations. Geophysical Research Letters, 33(17).

Froldi, P. (2000). Digital terrain model to assess geostructural features in near-vertical rock cliffs. Bull. Eng. Geol. Env., 59, 201-206.

Istituto Nazionale di Geofiscia e Vulcanologia (INGV), Osservatorio Vesuviano, sezione di Napoli (2017). [Available at http://www.ov.ingv.it/ov/bollettini-campi-flegrei/.]

Isaia, R., S. Vitale, M.G. Di Giuseppe, E. Iannuzzi, F.D.A. Tramparulo and A. Troiano (2015). Stratigraphy, structure, and volcano-tectonic evolution of Solfatara maar-diatreme (Campi Flegrei, Italy). 
Geological Society of America Bulletin, 127(9-10), 1485-1504.

Iuliano S., F. Matano, M. Caccavale and M. Sacchi (2015). Annual rates of ground deformation (19932010) at Campi Flegrei, Italy, revealed by Persistent Scatterer Pair (PSP) - SAR Interferometry. International Journal of Remote Sensing, 36, 24, 61606191.

Loke, M. H. (2014) Tutorial: 2-D and 3-D electrical imaging surveys. Geotomo Softwares, Penang. www. geotomosoft.com

Loke, M. H. and R.D. Barker (1996). Rapid leastsquares inversion of apparent resistivity pseudosections by a quasi-Newton method. Geophys Prospect 44:131-152. doi:10.1111/j.1365-2478.1996. tb00142.x

Maresca, R., N. Damiano, L. Nardone, M.A. Di Vito and F. Bianco (2014). A comparison of surface and underground array measurements of ambient noise recorded in Naples (Italy). Journal of seismology, 18(3), 385-400.

Matano, F., G. Esposito, R. Somma, T. Caputo, E. Marino, A. Pignalosa, M. Sacchi and G. De Natale (2015). Laser Scanning Application for Geostructural analysis of Tuffaceous Coastal Cliffs: the case of Punta Epitaffio, Pozzuoli Bay, Italy. European Journal of Remote Sensing, 48, 615-637. doi: 10.5721/ EuJRS20154834.

Matano, F., S. Iuliano, R. Somma, E. Marino, U. Del Vecchio, G. Esposito, F. Molisso, G. Scepi, G.M. Grimaldi, A. Pignalosa, T. Caputo, C. Troise, G. De Natale and M. Sacchi (2016). Geostructure of Coroglio tuff cliff, Naples (Italy) derived from terrestrial laser scanner data. Journal of Maps, 12 (3), 407-421. doi: 10.1080/17445647.2015.1028237

Moreira, C. A., Montenegro Lapola, M., \& Carrara, A. (2016). Comparative analyzes among electrical resistivity tomography arrays in the characterization of flow structure in free aquifer. Geofísica internacional, 55(2), 119-129.

Namson, J. and T. Davis (1988). Structural transect of the western Transverse Ranges, California: Implications for lithospheric kinematics and seismic risk evaluation. Geology, 16(8), 675-679.

Nyquist, J. E., Peake, J. S., \& Roth, M. J. (2007). Comparison of an optimized resistivity array with dipole-dipole soundings in karst terrain. Geophysics, 72(4), F139-F144.

Orsi, G., S. de Vita and M.A. Di Vito (1996). The restless, resurgent Campi Flegrei Nested Caldera (Italy): constraints on its evolution and configuration.
J. Volcanol. Geotherm. Res., 74, 179-214.

Orsi, G., Di Vito, M. A., \& Isaia, R. (2004). Volcanic hazard assessment at the restless Campi Flegrei caldera. Bulletin of Volcanology, 66(6), 514-530.

Rosi, M., \& Sbrana, A. (1987). Campi Flegrei, CNR Quad. Ric. Sci, 114(9), 175.

Sasaki, Y. (1994) 3D resistivity inversion using the finite-element method. Geophysics 59:1839-1848. doi:10.1190/1.1443571

Scarpati, C., A. Perrotta, S. Lepore, and A. Calvert (2013). Eruptive history of Neapolitan volcanoes: constraints from 40Ar-39Ar dating. Geological Magazine, 150, 412-425.

Somma, R., F. Matano, E. Marino, T. Caputo, G. Esposito, M. Caccavale, S. Carlino, S. Iuliano, S. Mazzola, F. Molisso, M. Sacchi, C. Troise and G. De Natale (2015). Application of laser scanning for monitoring coastal cliff instability in the Pozzuoli Bay, Coroglio site, Posillipo hill, Naples. In: Engineering Geology for Society and Territory, G. Lollino et al. (eds.), volume 5, DOI: 10.1007/978-3-319-09048-3319-09048-1_133. Springer International Publishing Switzerland 2015.

Somma, R., S. Iuliano, F. Matano, F. Molisso, S. Passaro, M. Sacchi, C. Troise and G. De Natale (2016). High-resolution morpho-bathimetry of Pozzuoli Bay, southern Italy. Journal of Maps Voume 12, pp. 222-230

Spichak, V. and A. Manzella (2009). Electromagnetic sounding of geothermal zones. Journal of Applied Geophysics, 68(4), 459-478.

Troiano, A., Z. Petrillo, M.G. Di Giuseppe, M. Balasco, I. Diaferia, B. Di Fiore, A. Siniscalchi and D. Patella (2008). About the shallow resistivity structure of Vesuvius volcano. Annals of Geophysics, Vol. 51, N. 1, doi: 10.4401/ag-3043.

Troiano, A., M.G. Di Giuseppe, Z. Petrillo and D. Patella (2009). Imaging 2D structures by the CSAMT method: application to the Pantano di S. Gregorio Magno faulted basin (Southern Italy). Journal of geophysics and engineering, 6(2), 120.

Troiano, A., M.G. Di Giuseppe, Z. Petrillo, C. Troise, and G. De Natale (2011). Ground deformation at calderas driven by fluid injection: modelling unrest episodes at Campi Flegrei (Italy). Geophys J Int 187:833- 847. doi:10.1111/j.1365246X.2011.05149.x

Troiano, A., M.G. Di Giuseppe, D. Patella, C. Troise and G. De Natale (2014). Electromagnetic outline of the Solfatara-Pisciarelli hydrothermal system, Campi Flegrei (Southern Italy). Journal of Volcan- 
ology and Geothermal Research, 277, 9-21.

Van Zijl J. S. V. (1985) A Practical Manual on the Resistivity Method. CSIR Report K79, CSIR, Pretoria, $p$ 136

Vitale, S.and R. Isaia (2014). Fractures and faults in volcanic rocks (Campi Flegrei, southern Italy): insight into volcano-tectonic processes. Int. J. Earth Sci. (Geol Rundsch), 103, 3 801-819.

Ward, S. H. (1990). Resistivity and induced polarization methods, in Ward, S.H., ed., Geotechnical and Environmental Geophysics, Volume I: Review and Tutorial: Society for Exploration Geophysics, Investigations in Geophysics 5, p. 147-189.

*Corresponding author: Maria Giulia Di Giuseppe,

Istituto Nazionale di Geofisica e Vulcanologia, Sezione di Napoli Osservatorio Vesuviano, Naples, Italy;

email: mariagiulia.digiuseppe@ingv.it.

2017 by Istituto Nazionale di Geofisica e Vulcanologia.

All rights reserved 